\title{
Imigração, fronteiras étnicas e sociabilidades: questões teóricas
}

\author{
Sergio Odilon Nadalin*
}

0 texto tem como referência sujeitos agrupados social e culturalmente a partir de um processo de emigração/imigração, cujas estruturas remontam às sociedades emissoras. Transcendendo o estabelecimento no município de Curitiba, Paraná, o grupo transforma-se gradativamente em contato com a sociedade brasileira e com outros agrupamentos de origem imigrante, erigindo fronteiras étnicas. Um dos direcionamentos da investigação foi conduzido por análises de comportamentos reprodutivos dos imigrantes e descendentes. O objetivo, neste estágio, é ultrapassar o porquê para tentar resolver o problema do como, apesar da ausência de documentação "qualitativa" que permitiria discernir a intimidade dos casais amostrados. Desse modo, colocam-se algumas questões teórico-metodológicas considerando o papel dos indivíduos, no âmbito do conceito das sociabilidades. Ou seja, na esfera das relações indivíduo-sociedade, investiga-se quais seriam as variáveis teóricas que poderiam ajudar a entender o que os números parecem denunciar. Para isso, consideram-se as relações interpessoais - incluindo o convívio intra e intergeracional - nos limites das mencionadas fronteiras. Com essa finalidade, a análise privilegia contextos que permitem sintetizar a dinâmica da etnicidade. Igualmente, propõe-se um balanço teórico-metodológico tendo como foco as minhas pesquisas, orientadas, num sentido epistemológico mais lato, por estudos "demográficos"; os dados de base foram amostrados a partir da metodologia da reconstituição de famílias.

Palavras-chave: Imigração. Etnicidade. Sociabilidade. Geração. Sexualidade. Comportamentos reprodutivos.

\footnotetext{
*Universidade Federal do Paraná (UFPR), Curitiba-PR, Brasil (sergion@terra.com.br; http://orcid.org/0000-0001-5091-2241).
} 


\section{Introdução}

Desde quando iniciei minhas pesquisas a respeito de sujeitos que se organizavam numa paróquia de confissão evangélica luterana, tenho argumentado que essa agregação constitui um grupo social (NADALIN, 1981). Como tal, deve ser estudada numa perspectiva de longa duração que transcenda o estabelecimento ${ }^{1}$ no município de Curitiba, Paraná, considerando os processos de emigração/imigração e a instalação anterior na Colônia Dona Francisca (SC). Grupo social, mas, da mesma forma, grupo cultural, cujas estruturas remontam às sociedades emissoras (SAHLINS, 2003; HALBWACHS, 1938); grupo cultural que, gradativamente, transforma-se em contato com a sociedade brasileira e com outros agrupamentos de origem imigrante, erigindo fronteiras étnicas (BARTH, 1998).

Um dos direcionamentos da investigação foi conduzido por análises de comportamentos reprodutivos dos imigrantes e descendentes (NADALIN, 1978; BIDEAU; NADALIN, 2011), com base principalmente num tratamento linear da história da paróquia (transição demográfica, urbanização). Tendo em vista necessidades metodológicas, distinguiram-se - a partir de sua fundação, em 1866 - três períodos, agregando casamentos registrados até 1894 , de 1895 a 1919 e de 1920 a 1939.

Neste estágio das investigações, estou tentando ultrapassar o porquê - eventualmente já respondido em trabalhos anteriores - para tentar resolver o problema do como, apesar da ausência de documentação "qualitativa” que permitiria discernir a intimidade dos casais amostrados. Foi assim que escrevi um trabalho auscultatório, enfocando o conceito das sociabilidades (NADALIN, 2019), com o objetivo de ultrapassar o conhecimento construído por meio de cifras obtidas por métodos demográficos (HENRY, 1970). Desse modo, o propósito deste artigo é colocar algumas questões teóricas (e metodológicas), a partir do entendimento do papel dos indivíduos. Ou seja, na esfera das relações indivíduo-sociedade (SIMMEL, 2006), pretende-se pensar quais seriam as variáveis teóricas que poderiam ajudar a entender o que os números parecem denunciar. Para isso, são consideradas as relações interpessoais - incluindo o convívio intra e intergeracional (MANNHEIM, 2006) - nos limites das fronteiras etno-culturais. Com essa finalidade, a intenção é privilegiar na análise diversos contextos que permitem sintetizar uma dinâmica da etnicidade (NADALIN, 2007). ${ }^{2}$

0 texto trata, igualmente, de fazer um balanço teórico-metodológico tendo como foco as minhas pesquisas orientadas, num sentido epistemológico mais lato, por estudos "demográficos" (NADALIN, 2004). Os dados de base foram amostrados a partir da reconstituição de famílias dos membros da Paróquia Evangélica Luterana (BIDEAU; NADALIN, 2011).

\footnotetext{
${ }_{1}^{10}$ termo traduz o ato de se estabelecer depois de imigrar, o que implicava as primeiras providências para o autossustento ou da família, a construção de um novo Heim (lar), o reconhecimento do local de instalação e das múltiplas afinidades culturais com os outros imigrantes, a análise das possibilidades de contato com a sociedade anfitriã, o planejamento para o futuro, etc.

${ }^{2}$ A partir de Barth, também diria que "a etnicidade é uma forma de organização social, baseada na atribuição categorial que classifica as pessoas em função de sua origem suposta, que se acha validada na interação social pela ativação de signos culturais socialmente diferenciadores" (POUTIGNAT; STREIFF-FENART, 1998, p. 141, grifo meu).
} 
Preliminarmente, constato a obviedade: o conjunto dos comportamentos reprodutivos do grupo que tem sido meu foco principal de pesquisas é fruto de uma história. Metodologicamente, ela foi decomposta em quatro partes (histórias de migrações, contatos culturais, histórias de gerações e histórias de sexualidades), que, mais ou menos (des)ordenadas, são apresentadas a seguir.

\section{Histórias de migrações e contatos culturais}

Primeiramente, são salientadas histórias de migrações; ou, talvez de forma mais pertinente, uma história de migrações. Colocá-la em evidência significa sublinhar este conceito para o grupo e destacar as influências culturais carregadas pelos imigrantes, coloridas pelos laços físicos e espirituais que mantinham e reconstruíam com a(s) sociedade(s) emissora(s). ${ }^{3}$ No caso da imigração germânica, os fluxos migratórios têm base relativamente contínua a partir do século XIX até pelo menos a década de 1930, sem considerar a lacuna concernente à Primeira Guerra Mundial.

As migrações articulam histórias de contatos culturais, que podem ser observadas de duas formas. Primeiramente, focando as sociedades emissoras. Os laços anteriormente aludidos começam a se desatar no momento da decisão da partida; uma corrente social, desde então, toma forma quando os sujeitos começam a se sentir membros de um agrupamento distinto. Este caracteriza-se por associar pessoas ligadas por ações, pensamentos e sentimentos próprios de sua condição; portanto, enfatizo, como Maurice Halbwachs (1938, p. 64), que os sujeitos concernentes seriam emigrantes antes mesmo de partirem. Esse parece ter sido o sentimento da família Strobel e de outros que deixavam Glauchau, na Saxônia, em fins de setembro de 1854. Gustav Hermann, um dos filhos do casal pioneiro, registrou o trauma da partida:

Se algum estranho os observasse, provavelmente julgaria que se tratava de um cortejo fúnebre [...]. Não era este o caso. Tratava-se de gente cansada da Europa, ou seja, emigrantes que decidiram deixar sua querida pátria por uma terra estrangeira, distante e desconhecida. (STROBEL, 2018, p. 36)

A ideia da corrente social pressupõe que a condição de emigrantes é fortalecida naturalmente não apenas quando vários partem da aldeia natal, mas também quando a eles se juntam passageiros com destino aos portos de imigração. Foi o caso dos viajantes que embarcaram no veleiro Florentin junto aos Strobel, ${ }^{4}$ assim como - agora imigrantes - aqueles que decidiram re-migrar da Colônia para outros lugares, como Curitiba. Assim, constituíam gradativamente um novo grupo, amalgamados pela situação em comum, por um idioma de origem germânica, a maioria professando a fé luterana e instalados num

\footnotetext{
$\overline{3}$ Independentemente da constituição do Império Alemão em 1870, os imigrante eram oriundos de diversas regiões da Europa Germânica, como Saxônia, Pomerânia, Suiç̧a, Schleswig-Holstein, Hamburgo e assim por diante.

${ }^{4}$ No veleiro embarcaram 213 emigrantes, dos quais 34 oriundos de Glauchau (BÖBEL; THIAGO, 2001, p. 172-179).
} 
meio relativamente desconhecido. Finalmente, continuam imigrantes até que, numa determinada geração, integram-se ou assimilam-se à sociedade anfitriã (HALBWACHS, 1938).

De outra forma, mirando agora a sociedade receptora, nas Américas, observam-se laços que, se por uma parte desprendem-se pela emigração, por outra permanecem atados à Europa, na longa duração. Em outros termos, as práticas oriundas das estruturas culturais mantiveram-se, apesar dos eventos assinalados pela emigração-imigração; ou melhor, foram preservadas, mas, ao mesmo tempo, reproduziram-se como novidades. ${ }^{5}$ De acordo com uma leitura de Sahlins, as migrações constituiriam fatos extraordinários contendo "o potencial de alterar substancialmente os significados tradicionais, de refazer relações e de criar o novo", integrando um efeito "revolucionário", excepcional (ANDREAZZA, 1996, p. 19). Desse modo, a experiência da migração trouxe, como consequência, a reposição "de estruturas passadas na orquestração do presente" - portanto, "ressignificadas" (SCHWARCZ, 2000, p. 129-130) e atualizadas na prática de um novo convívio na sociedade anfitriã. Diria que - veremos adiante - esta ressignificação toma novas formas à medida que se sucedem as gerações de imigrantes que se mantêm integrados à corrente social (HALBWACHS, 1938). Escrevi acima que histórias de migrações traduzem-se em histórias de contatos. Sem dúvida, sociais e econômicos; sobretudo, diria, contatos culturais! Também, contatos (continuidade dos fluxos imigratórios) e imateriais, que mantêm os elos com as sociedades emissoras por meio das aludidas correntes sociais; contatos que se estabelecem com as sociedades receptoras, a partir do estabelecimento imigrante.

Na perspectiva diacrônica, estes fenômenos relacionam imigrantes de origem germânica culturalmente diferenciados, isto é, oriundos de regiões e épocas distintas da Alemanha, o que se liga a proveniências sociais complexas (ANDREAZZA; NADALIN, 1994; NADALIN, 2019; MAGALHÃES; NADALIN, 2019). ${ }^{6}$ Considerando a hipótese da corrente social que perdura, um processo de etnicização acompanha o fenômeno da urbanização e as mudanças nas qualidades dos sujeitos da pesquisa. Em sua maioria passariam de estrangeiros para filhos de imigrados, de "alemães" para "teuto-brasileiros" (ou "brasileiros", conforme a perspectiva) e de pequeno-burgueses e camponeses para cidadãos urbanos. No final desta história, localizada pelo historiador em algum ponto do futuro, vislumbra-se a assimilação ${ }^{7}$ completa dos descendentes dos imigrantes alemães, tornados brasileiros, alguns ainda organizados na Paróquia.

Neste quadro, tomando-se o eixo do desenvolvimento da cidade, juntamente com a teoria da transição demográfica e da modernização, o resultado tenderia a demonstrar uma história determinada a priori. Assim explicar-se-iam as mudanças no comportamento reprodutivo, com a progressiva diminuição das influências camponesas e tradicionais e

\footnotetext{
${ }^{5}$ Diz muito melhor Marshall Sahlins (2003, p. 174): "a transformação de uma cultura também é um modo de sua reprodução".

${ }^{6}$ De origem pequeno-burguesa, Christian August Strobel nasceu em 12 de novembro de 1818, no lugarejo de Poppengrün, próximo a Falkenstein (Vogtland, Saxônia) e era filho de um proprietário rural e mestre-escola. Primogênito, decidiu aprender o ofício de carpinteiro, tendo mais tarde se estabelecido em Glauchau, onde se casou (STROBEL, 2018, p. 25-26). 0 exemplo mostra o íntimo relacionamento entre o rural e o urbano na Alemanha pré-industrial.

${ }^{7}$ Grifei o conceito pelo seu caráter mecanicista e linear, que acompanha o processo da urbanização e da modernização.
} 
o aumento das influências urbanas. Essas transformações teriam sido acompanhadas pela afirmação de comportamentos malthusianos ou neomalthusianos ${ }^{8}$ e pela redução gradativa das concepções pré-nupciais, relacionada ou não à utilização da contracepção (BIDEAU; NADALIN, 2011).

Explicações lógicas, mas embutindo uma armadilha. Afinal, trata-se de uma explicação mecanicista vislumbrada em perspectiva macro, mas que não explicaria porque, por exemplo, o ajustamento entre a mortalidade dar-se-ia de forma tão distinta entre algumas sociedades europeias (MCLAREN, 1997, p. 203). Para evitá-la, é necessário complicar convenientemente essa história, contextualizando-a - ou seja, questionando como aconteceu, de acordo com o mencionado na introdução desse trabalho. Para exemplificar, Phillip Kreager notou que o timing e ritmo dos declínios da mortalidade e da fecundidade e a seleção de mecanismos atinentes tendem a fugir da fórmula fixada - sem mencionar as causalidades e diferenças culturais (KREAGER, 1986, p. 137). Nesse sentido, buscando o que, dos dois lados das fronteiras étnicas, se falava e se dizia a respeito dos comportamentos concernentes, para além do que informam as cifras (MCLAREN, 1997, p. 203). Anoto que, procedendo desse modo, não estou desprezando os $n$ componentes herdados do passado, dialogando contraditoriamente com o presente: é assim que se apontam também, como objetivo deste trabalho, os encadeamentos da realidade balizados pelo início de observação das histórias matrimoniais. Encadeamentos que não se definem, necessariamente, por uma tendência à assimilação do grupo. Em outros termos, encadeamentos que, nos diferentes contextos em análise, poderiam explicar, na dialética com o pretérito, os comportamentos imbricados nas taxas e porcentagens calculadas.

Gustav Hermann escreveu suas memórias nas mesmas circunstâncias em que eram registradas na Igreja as núpcias distinguidas pelos anos de 1895 a 1919, período no qual se inserem os casamentos na segunda geração. 0 tom do manuscrito, em vários trechos, já parece mostrar que as diferenças culturais entre os imigrantes, seus filhos e a sociedade anfitriã estavam organizando-se socialmente num processo que permeava a construção de uma identidade. ${ }^{9}$ Nas entrelinhas de suas lembranças, destaco os efeitos, imediatos ou não, das hostilidades e dos preconceitos, das relações étnicas crescentes diante dos sucessos e das adversidades. Como membro de uma comunidade de imigrantes, suas atitudes não se pautavam necessariamente pelas suas heranças culturais: ao contrário, em função das situações de contato, o grupo do qual Gustav participava reorganizava-se aos poucos em torno do sentimento comum de pertença, da crença - muitas vezes mítica - na mesma origem (POUTIGNAT; STREIFF-FENART, 1998, p. 78-79).

\footnotetext{
${ }^{8}$ Sobre pré-malthusianismo, malthusianismo e neomalthusianismo, ver MacFarlane (1990, p. 45).

${ }^{9}$ Lendo Barth, Denys Cuche (2002, p. 201) refere-se à “etnicidade que é o produto do processo de identificação, pode ser definida como a organização social da diferença cultural. Para explicar a etnicidade o importante não é estudar o conteúdo cultural da identidade mas os mecanismos de interação que, utilizando a cultura de maneira estratégica e seletiva mantém ou questionam as 'fronteiras' coletivas”.
} 
Naturalmente em nome da mesma comunidade, o memorialista anota na introdução que seu manuscrito era destinado aos seus descendentes (STROBEL, 2018, p. 23). Era importante que soubessem como foi sofrida a migração, cujas lembranças, às vezes fantasiosas, eram parte da construída identidade étnica. Esta comportava igualmente a singularidade da confissão religiosa comum e da memória coletiva que refletia o relativo isolamento dos luteranos no seio de uma maioria católica (PRIEN, 2001, p. 90-93; HOBSBAWM, 2005, p. 218-219). A etnicidade constituía-se como resposta aos "outros", mormente em conjunturas de crise como aquela, eivada por especulações sobre o "perigo alemão" na conjuntura do Imperialismo e da Primeira Guerra Mundial. Especialmente nessas ocasiões, a comunidade teuto-brasileira sofria muitas críticas por parte não só da imprensa, mas também das autoridades da sociedade receptora (SEYFERTH, 1981, p. 144; FABRIS, 2014). ${ }^{10}$

Em relação aos costumes e à organização social da sociedade brasileira, Gustav tinha um olhar algumas vezes simpático e muitas vezes condescendente. De outra parte, era incansável no enaltecimento do que, acreditava, distinguia a cultura germânica. Assim, para a construção de uma vida boa e decente, e para a devida contribuição ao progresso, valorizava a moral, a ética e o "trabalho alemão", o protestantismo e o anticlericalismo (relativo ao catolicismo) e a língua materna.

Com poucas exceções, os escritos de Gustav Hermann revelam a normalidade das relações na esfera do grupo etno-cultural e indicam a variedade dos contatos com a sociedade curitibana, em especial motivados pelas relações de trabalho. Da mesma maneira, apontam para um homem viajado, o que the permitiu manter contatos relativamente frequentes com outros corpos sociais teuto-brasileiros e, o que é similarmente sintomático, com os descendentes dos alemães que não emigraram, principalmente da Saxônia. Assim, também revelam que, na edificação da ideologia étnica teuto-brasileira (Deutschbrasilianertum), à experiência curitibana agregar-se-ia a de indivíduos que pertenciam a diversas comunidades “coloniais" instaladas no Brasil. 0 autor torna implícita, dessa forma, sua pertença à "colônia", congregando vários agrupamentos teuto-brasileiros, revelando histórias distintas de aculturações (WACHTEL, 1974; POUTIGNAT; STREIFF-FENART, 1998, p. 72; WILLEMS, 1980). Provinham não só de deslocamentos de indivíduos e dos contatos resultantes, mas também das migrações de ideias oriundas da Europa ou geradas pela intelligentsia teuto-brasileira, salientando-se certos jornais e a literatura original veiculada principalmente nos Kalender (SEYFERTH, 1981, p. 107-124). ${ }^{11}$

Salientei indivíduos. Logo, sintetizando, diria que a etnicidade constrói-se a partir de cada experiência individual na trama e urdidura da coletividade cultural, associada aos contatos interpessoais no contexto da sociedade maior - sempre incluindo a práxis dos contatos intergeracionais. No caso, incluo o entorno definido pela sociedade curitibana

\footnotetext{
${ }^{10}$ Sobre uma cultura teuto-brasileira, enfatizando a literatura, ver Seyferth (2004).

${ }^{11}$ Os Kalender eram almanaques ou anuários, publicados a partir da década de 1870. Eram veículos de comunicação muito populares, abordando "assuntos diversos, inclusive traduções para o alemão de textos de autores brasileiros, principalmente poesias, divulgação de contos e romances de autores alemães e teuto-brasileiros, além de muitas informações práticas destinadas aos colonos" (HUBER, s/d).
} 
e as experiências desenvolvidas por meio da convivência entre as diversas comunidades de origem imigrante.

Giralda Seyferth (2003, p. 60) concluiu que os teuto-brasileiros assumiram sua etnicidade quando se rompeu o isolamento das colônias. No processo de urbanização e modernização, Curitiba direcionava-se a uma efervescência característica no final dos novecentos, desenvolvendo-se como uma "cidade polêmica, cadinho de nacionalidades, crenças e opiniões” (TRINDADE, 1996, p. 105). Neste processo, intensificaram-se contatos distintivos, o que salientou identidades étnicas (POUTIGNAT; STREIFF-FENART, 1998, p. 124). Em especial na capital paranaense, parece-me que as relações de convívio tiveram seu amadurecimento colocado à prova nas intenções organizativas desenvolvidas pelos imigrantes a partir da década de $1860 .^{12}$

Consequentemente, isto teria ocorrido associado à superação da fase do estabelecimento, 10 a 15 anos após o início do fluxo de imigrantes oriundos de D. Francisca, sendo fundamental para o avanço do sentimento teuto-brasileiro. Dessa maneira, organizaram-se sociações, ${ }^{13}$ particularmente com a fundação dos Vereine,${ }^{14}$ "determinadas formas de estar com o outro e de ser para o outro", assumindo formas lúdicas de sociabilidades. ${ }^{15}$

Dessa forma, as fronteiras culturais que isolavam o estabelecimento inicial foram substituídas gradativamente por fronteiras étnicas (POUTIGNAT; STREIFF-FENART, 1998, p. 152-153). Isso teria ocorrido tendo em vista que as categorias imigrantes e descendentes começaram a se sentir diferentes dos outros, do-lado-de-lá; estes, por sua vez, começavam a vivenciar de maneira diversa a novidade dos agrupamentos coloniais, sobretudo protestantes. Com efeito, um item importante para a coesão do grupo estava na profissão de fé, que estruturava os comungantes na paróquia. Este fato marcava um novo cenário para a sociedade brasileira, uma vez que a população católica romana, "mesmo sem contato litúrgico, não podia fugir a essa intrusão” (RIBEIRO, 1973, p. 81; 91). Portanto, os teuto-brasileiros imprimiram sua marca no desenvolvimento da cidade com sua presença física e espiritual, o que caminhava pari passu ao endurecimento das representações sociais e das tensões urbanas.

É nesse ambiente que Gustav Hermann, ao se casar, em 1875, deixava para trás o status de solteiro e a relativa dependência do pai, estabelecendo domicílio na "cidade".

\footnotetext{
12 A primeira associação fundada por imigrantes em Curitiba foi o Gesangverein Germania, em 1869 (NADALIN, 1972). Embora tecnicamente associação, não incluí neste privilégio do Germania a Evangelische Kirche Gemeinde (Comunidade da Igreja Evangélica, 1866) e a Friedhofsverei (Associação do Cemitério), ainda anterior. No que concerne à fundação da Igreja Evangélica, a lista comunitária que se compromete a sustentar a comunidade não incluía a família Strobel, o que parece mostrar que, indivíduo por indivíduo, o mencionado "amadurecimento" não contempla ao mesmo tempo todos os imigrantes (ver MACHADO; NADALIN, 2018, p. 214).

${ }^{13}$ Simmel (2006, p. 60) define, "simultâneamente, como conteúdo e matéria da sociação, tudo o que existe nos indivíduos e nos lugares concretos da realidade histórica como impulso, interesse, finalidade, tendência, condicionamento psíquico e movimento nos indivíduos - tudo o que está presente nele de modo a engendrar ou mediatizar os efeitos sobre os outros, ou a receber esses efeitos dos outros".

${ }^{14}$ Até 1926, estima-se que meia centena de entidades de origem teuto-brasileira foram fundadas em Curitiba (NADALIN, 1972, p. 4).

${ }^{15}$ Tomo de empréstimo a definição de Simmel (2006, p. 65, grifo do autor): "sociabilidade”, a forma lúdica de sociação.
} 
As particularidades de suas recordações caracterizam descontinuidades cronológicas. Parecem "saltar" diretamente para imagens no passado, recriado em função de lembranças provavelmente enviesadas pelas conversas com os pais e pelas condições especiais da conjuntura da virada do século XX. ${ }^{16} \mathrm{~A}$ lacuna cronológica não contemplada pelo autor deve ser preenchida pelo historiador, considerando a gradatividade do processo de construção da identidade étnica. Assim, é provável que, na época do casamento, já se identificasse nele um sentimento de germanidade.

Em outros termos, estou tentando conduzir a ideia da importância dos indivíduos partícipes do grupo social, que não é simplesmente a soma deles; no processo do estabelecimento ocorreria "um novo fenômeno que surge não da individualidade plena de cada um dos seus participantes, mas sim daqueles fragmentos de cada um que coincidem com os demais" (SIMMEL, 2006, p. 50). Na mesma direção, mas pensando em especial na etnicidade, completo com o que diz o mesmo autor, em outra página:

O indivíduo é pressionado, de todos os lados, por sentimentos, impulsos ou pensamentos contraditórios, e de modo algum ele saberia decidir com segurança interna entre suas diversas possibilidades de comportamento - que dirá com certeza objetiva. Os grupos sociais, em contrapartida, mesmo que mudassem com frequência suas orientações de ação, estariam convencidos, a cada instante e sem hesitações, de uma determinada orientação, progredindo assim continuamente; sobretudo saberiam sempre quem deveriam tomar como inimigo e quem deveriam considerar amigo. (SIMMEL, 2006, p. 40, grifos meus)

No caso da população de origem germânica, esta orientação em determinada direção, estes fragmentos de similaridades e afinidades sintetizam a identidade comum e, eu salientaria, a comunhão de fé, a origem imigrante (acompanhada dos seus mitos), o elo da germanidade e da teuto-brasilianidade - ou, respectivamente, do Deutschtum e do Deutschbrasilianertum (SEYFERTH, 1994). Identidade definida, repito, pelo contato com o outro no âmbito de uma mesma "sociedade global" (LAPIERRE, 1998, p. 9). Comunidade que se etnicizava, resultado de tensões sociais geradas na cidade que se urbanizava e se aparelhava para a convivência entre uns e os demais. Enfim, comunidade que significava a interação de indivíduos, a partir de determinados impulsos, motivados por interesses diversos, objetivos ou subjetivos, religiosos, étnicos, amorosos, eróticos... Agrego que Georg Simmel não estava pensando propriamente em questões étnicas ao refletir sobre a “sociedade”. De qualquer forma, é possível pensar nelas na formulação relacionada à interação entre indivíduos, "em uma relação de convívio, de atuação com referência ao outro, com o outro e contra o outro, em um estado de correlação com os outros. Isso quer dizer que ele exerce efeito sobre os demais e também sofre efeitos por parte deles" (SIMMEL, 2006, p. 60). Diria, portanto, que relações de sociabilidades constituiriam condição para que um agrupamento se etnicizasse, embora, para isso, fossem necessárias formulações

\footnotetext{
${ }^{16}$ A conjuntura foi, de forma apropriada, denominada por Hobsbawm na Era dos impérios (2005), sendo caracteristicamente sentida a partir da década de 1900 até o final da Primeira Guerra Mundial (NADALIN; FABRIS, 2013; FABRIS, 2014).
} 
mais objetivas. 0 outro lado da moeda parece conduzir o fato de que o caráter dessas sociações constituiria a forma de superar os marcos da confraria étnica: as fronteiras limitam o grupo, mas, mais ou menos fluidas, moventes e permeáveis (POUTIGNAT; STREIFF-FENART, 1998, p. 154), são atravessadas e ultrapassadas pelas pessoas.

No que toca ao indivíduo, cada um é um, por definição. Todo teuto-brasileiro (assim mesmo, no singular) tem um vínculo especial com o futuro, sintetizado nos sonhos e utopias da comunidade - nesse sentido, o grupo é teleologicamente determinado (SIMMEL, 2006, p. 61). Por conseguinte, futuro idealizado, futuro planejado; enfim, futuro que constitui referência, futuro que, do mesmo modo, orienta o grupo étnico. Na perspectiva da dinâmica populacional, entrando também em linha de conta dos casais que, consciente ou inconscientemente, "planejam" o número de filhos, ao assumirem comportamentos malthusianos.

Ao mesmo tempo, a referência é o passado. Demograficamente, representado pelos pais, avós e antepassados; da mesma forma, pelas reminiscências que contabilizavam os filhos dos ancestrais. Socialmente, amalgamando-se na memória coletiva, o que permite explicar a endogamia relativa da congregação em Curitiba - em certas décadas, quase absoluta. Passado e futuro que constituem, e isso é fundamental para entender cada contexto, referências para o presente. Em cada momento considerado, é provável que o casamento e os ritos próximos (as convenções relacionadas às aproximações entre rapazes e garotas, ao namoro, ao noivado) constituam a última fronteira a ser ultrapassada pelos membros de um agrupamento etno-cultural (WILLEMS, 1980, p. 322-323). Todavia, posso imaginar tranquilamente flertes e olhares entre gêneros distintos transpondo limites étnicos (NADALIN, 2019).

Encurtando, quis destacar que, desde as migrações, avalio que são os comportamentos dos indivíduos que permitem entender como, caso a caso, constrói-se a problemática da etnicidade: a história da família Strobel, mencionada, demonstra de que forma, a partir do estabelecimento inicial, estes sujeitos erigiram fronteiras, agregados à comunidade. São as ações individuais que me permitem melhor entender o dinamismo da identidade étnica, para a qual contribui o cruzamento das balizas etno-culturais.

Por outra parte, penso na utilização da autobiografia de um indivíduo, como Gustav Hermann, quando se torna o centro das nossas atenções. A partir da seleção de memórias que nos deixou, é possível conhecer o personagem, embora não em toda a sua complexidade. ${ }^{17}$ Por outro lado, ao relacioná-lo ao "grupo" ou a um "grupo etno-cultural" (ou à "sociedade"), poderíamos aventar que este "constructo intelectual” (SIMMEL, 2006, p. 10) "seria uma abstração indispensável para fins práticos, altamente útil também para uma síntese provisória dos fenômenos, mas não um objeto real que exista para além dos seres individuais e dos processos que eles vivem". (SIMMEL, 2006, p. 8). Da mesma forma, a "comunidade", à qual tenho recorrentemente me referido, constitui uma abstração: no

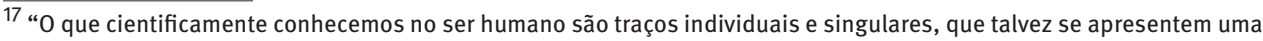
única vez, talvez mesmo em situação de influência recíproca, e em cada caso exige uma percepção e dedução relativamente independentes" (SIMMEL, 2006, p. 12).
} 
tempo, passam os indivíduos - e as gerações -, os caracteres, as crenças, as ideologias etc., mas, de igual maneira, mudam-se os contextos das relações étnicas.

Entretanto, é impossível fugir ao fato de que "tudo o que os seres humanos são e fazem [...] ocorre dentro da sociedade, é por ela determinado e constitui parte de sua vida" (SIMMEL, 2006, p. 9), o que, naturalmente, permite a utilização dos escritos de Gustav como fonte histórica. Além disso, considere-se a obviedade, importante para as alegações teóricas deste texto: agrupamentos e indivíduos concernem a temporalidades distintas, as durações relativamente longas dos grupos contendo a transitoriedade do ciclo vital (SIMMEL, 2006, p. 39); permito-me acrescentar que, pelas mesmas razões, os grupos de indivíduos que constituem gerações também são contingentes. ${ }^{18}$ Entretanto, essas transitoriedades nuanceiam-se pela continuidade ou permanência dos interesses que mantêm unido o corpo social.

Assim sendo, volto-me novamente ao interesse antes anunciado pela história dos comportamentos reprodutivos na congregação dos luteranos em Curitiba. Nessa direção, justifica-se o recorte teórico-metodológico centrado nas coortes e gerações.

\section{Histórias de gerações}

História de migrações, história de contatos culturais. Mas, igualmente, história de indivíduos agregados num conjunto etno-cultural reunidos em coortes e (ou) gerações. Muitas vezes tomada como sinônimo de geração, anoto que, na demografia, a coorte constitui um conjunto de indivíduos que experimentaram acontecimentos similares durante um determinado período (DICIONÁRIO DEMOGRÁFICO, [1969], p. 18). ${ }^{19}$ Para esta exposição, os casais reunidos em cada coorte distinguem-se pela experiência diversa que tiveram nas histórias dos ciclos matrimoniais. Em outras palavras, agregados em gerações distintas, os indivíduos e casais concernentes vivenciaram de forma diferenciada cada período da história.

É possível afirmar que Gustav Hermann e os indivíduos nascidos em 1849 fizeram parte da mesma geração - desde que houvesse, naturalmente, um vínculo social entre eles. ${ }^{20}$ A possível ligação existiria se todos tivessem nascido na Saxônia ou, coincidentemente, na conjuntura em que se assinalavam as causas e efeitos das Revoluções de 1848. Estas afetaram enormemente Christian e Christianna Strobel, pais de Gustav, e teriam sido a razão para sua emigração (STROBEL, 2018).

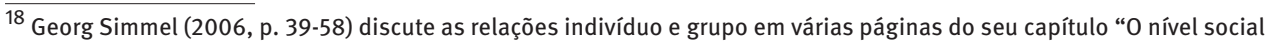
e o nível individual”. De outro lado, discute a relação entre os diversos níveis de aproximação no que tange à necessidade de se chegar à "verdade" (SIMMEL, 2006, p. 14). Pensando como Barth no que concerne à identidade do grupo étnico, "os traços que levamos em conta não são a soma das diferenças 'objetivas' mas unicamente aqueles que os próprios atores consideram como significativos" (LAPIERRE, 1998, p. 11).

${ }^{19}$ Por exemplo, neste estudo, as coortes de casamentos celebrados entre 1866 e 1894, 1895 e 1919, 1920 e 1939.

${ }^{20}$ Em trabalho relativamente recente, Alda Britto da Motta (2004, p. 350) passa sinteticamente em revista o significado do termo "gerações", discorrendo sobre a influência estatística ou demográfica, a tradição antropológica e a contribuição da Sociologia no que concerne a este conceito.
} 
Pensando no conceito sociológico, poderíamos ampliar/modificar o recorte, agregando Gustav e seus irmãos a uma geração de imigrados. Nesse caso, seria possível informar que fizeram parte de uma coorte de imigrantes identificados pelos anos de, digamos, 1846-1853 e nascidos em Glauchau. Poderíamos, como um demógrafo, fazer referência concretamente à geração de imigrantes que nasceram em 1830 em algum lugar da Alemanha e que desembarcaram em 1854 no porto de São Francisco do Sul (como o pai de Gustav, por exemplo). Estes viajantes teriam passado por um estado de espírito e um estilo de sensibilidade particulares, causados pela emigração/imigração e, sobretudo, por um sentimento de comunidade intelectual que lhes propiciou uma experiência histórica compartilhada (BURGUIÈRE, 1994, p. 15; HALBWACHS, 1938). Finalmente, aproximamo-nos de um senso comum quando convencionei que os indivíduos que se casaram no período 1895-1919 constituiriam uma segunda geração, quase todos filhos de imigrantes. Os casais unidos no período seguinte, de 1920 a 1939, agregar-se-iam na terceira geração: seriam, na maioria, netos de imigrantes, muitos nascidos em Curitiba e no seio de um grupo étnico.

Ao derivarmos para o conceito sociológico de geração, cabe observar a dificuldade em se definir exaustivamente este recorte, "mesmo porque são discutíveis as possibilidades de utilização de qualquer critério objetivo para a demarcação geracional" (COLOGNESE, 2011, p. 143) - afinal, quando termina uma geração para dar lugar a outra? (MOTTA, 2004, p. 349). Analisado o problema na perspectiva das coortes que determinei, as fronteiras aparentemente concretas, porque datadas, desconsideram a nebulosidade própria dos limites. E, no entanto, arbitrariamente as definimos, muitas vezes, por necessidade metodológica; foi o que fiz, quando agrupei minhas fichas de família em função de períodos de casamento. Porém, é aí que se encontra o nó da questão concernente aos recortes, ainda mais porque é nas zonas fronteiriças que "se constroem e se reconstroem as identidades geracionais, assim como os conflitos e as estigmatizações" (COLOGNESE, 2011, p. 140).

Juntamente com os irmãos e outros filhos de imigrantes, Gustav Hermann e sua mulher agrupavam-se na coorte de casamentos atinentes ao que chamo de primeira geração. Valendo o exemplo da linhagem fundada pelos pais, tudo se passa como se, em algumas gerações, os descendentes dos pioneiros fossem continuamente substituídos por novos componentes nas coortes de matrimônios. Ou, diria, o nós incorpora sucessivamente novos membros e grupos geracionais, nascidos no domínio da paróquia; como as migrações não cessam, elas associam de forma contínua novos atores, oriundos do estrangeiro e de outras regiões do Brasil; portanto, novas gerações, distintas nas próprias singularidades.

O nós também agrega, em função de fatores diversos, pessoas casadas com outsiders que, assim, incorporam-se eventualmente à congregação. Da mesma forma, soma indivíduos a partir de sociabilidades desenvolvidas sobretudo do-lado-de-cá, mas, de modo igual, do-lado-de-lá dos limites étnicos. Portanto, intra e intergeracionalmente, indivíduos atravessam as persistentes, mas porosas, fronteiras etno-culturais. De maneira inversa, o grupo perde (ou exclui) indivíduos pelos mesmos, ou outros, motivos: são pessoas que transpõem eventual ou permanentemente as referidas fronteiras. 
Com efeito, a identidade correspondente, como qualquer outra, resulta de uma construção social e, por isso mesmo, faz parte da sua complexidade. Em outros termos, as identidades culturais (ou etno-culturais) não podem se reduzir a definições simples e “puras” (CUCHE, 2002, p. 192). Isso seria desconsiderar a heterogeneidade das diversas gerações que compuseram o conjunto de imigrantes e descendentes em Curitiba e, da mesma forma, da sociedade curitibana, em cuja história se movimentam nossos atores. Heterogeneidade que levava, por suposto, a distintos processos de contatos culturais e de etnicização.

É na efervescente urbanização que essas relações são otimizadas, principalmente se, como vimos com Gustav Hermann Strobel, nesse processo verifica-se a ascensão social e econômica dos sujeitos. De uma condição inicial de relativa penúria e de identificação cultural à sociedade emissora, Gustav e os irmãos etnicizaram-se ao longo dos respectivos ciclos vitais, tendo em vista que passaram por situações comuns na "mesma dimensão histórica do processo social” (MANNHEIM, 1982, p. 71).

Essa hipótese parece se confirmar ao observarmos a biografia deste filho de imigrante que, ao amadurecer no mundo do trabalho e em contato com outros membros do grupo e com a sociedade brasileira, aprendeu o português e a se relacionar com outrem, e se etnicizou. Em outras palavras, o processo concernente pode ser observado de um período e (ou) de uma geração para outra; e, como ocorreu com Gustav, durante o ciclo de vida atinente e no campo da própria geração.

Trata-se de dinâmica ligada ao processo de crescimento, no sentido mais amplo, da cidade que os acolheu. Todavia, como venho insistindo, o processo não é simplesmente contínuo ou sequencial. Tenho como referência, por exemplo, a conhecida Lei de Hansen, ${ }^{21}$ uma vez que a etnicidade manifesta-se a partir de certo momento (não exatamente na terceira geração, como propunha o historiador): diria que quando os imigrantes e/ou descendentes atingem posições seguras - o que pode variar caso a caso - é que "se dão ao luxo" de manifestarem comportamentos étnicos (POUTIGNAT; STREIFF-FENART, 1998, p. 138). Nesse caso a caso, também devemos supor - é o que entendi a partir de Hansen - que o processo de "formatação" e definição dos conteúdos desses comportamentos étnicos não é linear. Portanto, é necessário ponderar que este "certo momento", em cada contexto observado, também diz respeito ao comportamento individual e ao ciclo vital de cada membro do grupo.

Os pais de Gustav Hermann Strobel, assim como ele e sua mulher, filhos e netos, conviveram ao mesmo tempo "com pessoas da mesma e de diferentes idades [...] mas para cada uma 'o mesmo tempo' era um tempo diferente" (MANNHEIM, 1928, p. 124 apud MOTTA, 2004, p. 351, grifo meu). Dito de outra forma, refiro-me às temporalidades distintas ligadas contraditoriamente num mesmo contexto, ensejando reações diferentes de cada

\footnotetext{
21 “O historiador Marcus Lee Hansen sugeriu em 1937 o que ficou conhecido como 'Hansen's Law' - a ideia de que a primeira geração emigra (sic), a segunda esquece (assimila), mas a terceira retorna às suas origens” (GREEN, 2008, p. 29; HANSEN, 1938).
} 
geração que experiencia os mesmos acontecimentos: "cada momento histórico se realiza com a presença simultânea de várias gerações que, mesmo contemporâneas, não tem as mesmas experiências e trajetórias de vida" (MOTTA, 2004, p. 351). Aventaria, dessa forma, acrescentar à dialética das durações braudelianas (BRAUDEL, 1969, p. 41-83) uma quarta dimensão temporal, atinente às coortes e gerações. 0 modelo construir-se-ia assim: a longa duração concernente ao "grupo social”, com ramificações anteriores à emigração/ imigração; o "tempo médio" referente aos contextos; o tempo finito do ciclo vital do indivíduo e dos agregados correspondente às gerações; e, finalmente, o tempo curto relativo aos acontecimentos, à microestrutura.

A dialética entre indivíduos de idades diferentes que vivem contraditoriamente o mesmo "tempo" poderia explicar conflitos de gerações. Assim, por exemplo, quando pensamos o ancião experienciando com um jovem o mesmo "presente", a modernidade deste consiste em estar mais próximo dos problemas atuais e no fato de "estar dramaticamente consciente de um processo de desestabilização e tomar partido nele. Durante tudo isso, a geração mais velha se agarra à reorientação que foi o drama de sua juventude" (MANNHEIM, 1982, p. 83, grifo do autor).

Dessa maneira, a relação, num mesmo período, entre os casais que se agregam nas três coortes de casamentos, aqui em referência, poderia ser configurada como "conflito" de gerações, o que poderia explicar - pelo menos parcialmente - a dinâmica histórica do grupo luterano em Curitiba, da década de 1860 até a de 1930 (NADALIN, 2007). Os grupos de idade agrupados em cada coorte associam gerações de indivíduos, que quero aqui salientar. Foram esses grupos objeto das preocupações de Mannheim, que pretendeu estudá-los em perspectiva sociológica. Tal como os demógrafos, ele partiu de uma formulação biológica do problema, cujas situações baseiam-se no ritmo da vida humana: nascemos, vivemos e morremos, passando pelo processo de envelhecimento. "Os indivíduos que pertencem à mesma geração, que nasceram no mesmo ano, são dotados, nessa medida, de uma situação comum na dimensão histórica do processo social” (MANNHEIM, 1982, p. 71). ${ }^{22}$ É dessa forma que a agregação de indivíduos a um grupo étnico constitui um nexo concreto que pode ser descrito "como a participação do destino comum" do referido grupo (MANNHEIM, 1982, p. 85-86, grifo do autor).

Fica da mesma maneira registrado, para concluir esta questão, que o conceito demográfico de geração é relativamente flexível. Em outro lugar deste texto, afirmei que seu conteúdo permite agregar indivíduos nascidos - por exemplo - num determinado ano, mas também em determinado período de tempo. Embora convenção, o "ano" é bem preciso; mas o que dizer do "período"? Se, de um lado, os historiadores (entre outros) entendem que a geração constitui uma categoria dinâmica, capaz de dar conta das mudanças internas

\footnotetext{
22 De outro modo, geração é um "coletivo de indivíduos que vivem em determinada época ou tempo social, têm aproximadamente a mesma idade e compartilham alguma forma de experiência ou vivência" (MOTTA, 2004, p. 350). Mais do que nascer na mesma região histórica e cultural, é necessário "um nexo mais concreto [...] para que a geração se constitua como uma realidade. Esse nexo mais concreto pode ser descrito como a participação do destino comum dessa unidade histórica e social” (MANNHEIM, 1982, p. 85-86, grifo do autor).
} 
e, sobretudo, culturais que afetam a sociedade, de outro, como medir seu peso sem considerar a definição estritamente demográfica? (BURGUIÈRE, 1994, p. 15). ${ }^{23}$

\section{Histórias de sexualidades ${ }^{24}$}

Ao introduzir este texto, deixei implícito que, no horizonte do meu projeto, delineia-se o direcionamento definido pelas análises de comportamentos reprodutivos manifestados por imigrantes germânicos e descendentes. Assim, as reflexões teórico-metodológicas desenvolvidas têm como objetivo a busca de um caminho, aprofundando abordagens já realizadas, para o entendimento destes comportamentos.

Sem dúvida, os mencionados comportamentos remetem inicialmente à fertilidade (combinada com a sexualidade) e à fecundidade feminina. Nesse sentido, quero entender o que está por detrás das taxas de concepções pré-nupciais e das médias de idade do casamento nas diversas coortes, quando são observados comparativamente números relativos a jovens adolescentes (menos de 20 anos) e adultas (20 anos ou mais). Desse modo, para além de hábitos e comportamentos, está no meu horizonte o amadurecimento biológico das meninas e moças, acompanhado naturalmente pelo desenvolvimento da libido. ${ }^{25}$ Como poderia dizer Foucault (1977, p. 11-12), taxas difíceis de decifrar - inclusive porque, mais complicado do que a explicação biológica da concepção, é entender a respectiva cultura. ${ }^{26}$

Como foi citado, parti de um recorte sugerindo três períodos de casamentos, que marcariam as histórias matrimoniais de gerações de jovens da paróquia luterana em Curitiba. 0 resultado é integrado por três situações, traduzidas em cifras, que demandariam contextualização. 0 período anterior a 1895 foi objeto de trabalho recente (NADALIN, 2019) e mostrou como a longa duração que define o grupo etno-cultural tem raízes nas estruturas anteriores à emigração (SAHLINS, 2003). Neste momento, a comunidade ainda formaria um enclave, cujos contatos com a sociedade anfitriã eram limitados. A fecundidade calculada para a primeira coorte de casais caracterizava, de maneira um tanto difusa, comportamentos pré-malthusianos. A relativa ausência da utilização de métodos contraceptivos parecia ser coerente, no lato senso, com os índices de concepções pré-nupciais; tal fato reforçaria a

\footnotetext{
${ }^{23}$ Na definição das coortes para a pesquisa, pareceu-me coerente dividir o período concernente à reconstituição de famílias do grupo, de 1866 a 1919 - ou seja, 53 anos - em dois períodos de casamentos, um de 28 anos e outro de 25 (NADALIN, 1978). A coorte posteriormente agregada baseou-se num período mais curto, de 19 anos, uma vez que decidi fechar a observação em 31 de dezembro de 1939 (BIDEAU; NADALIN, 2011). De todo modo, o "tamanho" das coortes assim definidas corresponde aproximadamente ao que se considera, no senso comum, uma geração, que pode ser entendido como um período de 30 anos. Por outro lado, a duração concernente tem como referência um "período histórico" que corresponderia tradicionalmente à duração da renovação dos homens na vida pública, medida pelo espaço de tempo que separa a idade do pai daquela do filho (SEGALEN, 1993, p. 191).

${ }^{24}$ Sobre o tema existe uma vasta bibliografia que não ouso elencar, exaustiva como é. Entretanto, posso exemplificar com alguns autores: Adler (1990); Ariès (1992); Coontz (2006); Corbin (1992); Flandrin (1983); Foucault (1977); Murstein (1978); Rohden (2006); Shorter (1995); Stearns (2010); Tannahill (1982).

${ }^{25}$ Para esclarecimentos técnicos, ver Oliveira et al. (2016, p. 200).

${ }^{26}$ Ver um resumo da questão em Ressel e Gualda (2003, p. 83). Ver também Fonseca e Lucas (2009, p. 65).
} 
postulação da sexualidade construída culturalmente - em síntese regulada por antigas tradições e por uma visão de mundo distintiva em um "isolado" cultural.

O panorama muda nas duas coortes seguintes, cujos casais adotam de forma mais clara comportamentos contraceptivos nas relações maritais e, eventualmente, nas relações anteriores ao casamento. Modificam-se os comportamentos porque os contextos são distintos, e mudam as relações com o passado e o futuro; altera-se o cenário, uma vez que cada presente é colorido por contatos étnicos que têm dinâmica própria. Esses contatos, como diria o antropólogo, priorizam "teias de significados e relações sociais que se sustentam em um determinado contexto" (HEILBORN; BRANDÃO, 1999, p. 8). ${ }^{27}$ Dito de outra forma, o significado do sexo para a primeira coorte não era necessariamente o mesmo para a segunda, e menos ainda para a terceira (HEILBORN, 1999, p. 40); por outro lado, na perspectiva de gerações superpostas num mesmo contexto, a sexualidade seguramente não teria o mesmo grau de importância para indivíduos de idades distintas. Ainda mais porque o fundo destes contextos também se diferencia: o primeiro definido pela herança pequeno-burguesa e camponesa (NADALIN, 2019); e os dois subsequentes imersos num processo de urbanização.

Assim é que, de uma geração para outra, mudam-se os costumes relativos à sexualidade, como mudam-se os significados concernentes aos filhos e às relações sexuais pré-nupciais. No contexto do enclave inicial em Curitiba, o isolamento e a presença de costumes antigos poderiam explicar as elevadas taxas de fecundidade e de concepções pré-nupciais. Porém, deve-se ponderar que não é necessariamente em função da urbanização que se modificam os costumes; por certo, a dinâmica do contexto urbano age de forma diferente sobre as relações étnicas e sobre os comportamentos reprodutivos. Em Curitiba, provavelmente, como em outras cidades nas quais a presença germânica era importante, as filhas de teuto-brasileiros eram menos vigiadas do que as filhas solteiras de famílias luso-brasileiras nos passeios "à noitinha”, nas visitas e na frequência a festas e bailes. E, eu completaria, durante o namoro e o noivado, o que parece ter levado à relativa frequência de concepções pré-nupciais. Em decorrência, talvez exorbitando conclusões de Emilio Willems (1980, p. 320-321), sugere-se que essas tradições dos descendentes dos imigrantes alemães derivaram para uma relativa indulgência relacionada à virgindade feminina e para a intolerância quanto à prostituição. Do lado-de-lá das fronteiras étnicas, a opinião pública era intransigente no que tange aos deslizes das "moças de boa família”, mas complacente quanto ao "instinto sexual masculino" e à prostituição (TRINDADE, 1996, p. 212-240).

Meus argumentos desenvolvem-se a partir de um quadro de relações etno-culturais. Sendo assim, parece-me lógico aventar que a sexualidade, antes e depois do casamento,

\footnotetext{
$\overline{27}$ Numa abordagem social construtivista, argumenta-se a respeito da existência de "formas culturalmente específicas [...] que envolvem contatos corporais entre pessoas do mesmo sexo ou de sexos diferentes, ligados ou não à atividade reprodutiva, que podem ter significados radicalmente distintos entre as culturas, ou mesmo entre grupos populacionais de uma determinada cultura" (HEILBORN; BRANDÃO, 1999, p. 9).
} 
varie em função da história cultural e da organização social de determinada comunidade; ou, se caso for, da biografia/trajetória sexual dos indivíduos - considerando sempre, e eu sublinho, o contexto (LOYOLA, 1999, p. 36). ${ }^{28}$ Este ambiente deve considerar, a partir do que está colocado, luteranos de origem imigrante e teuto-brasileira e católicos de origem portuguesa que conformavam de maneira distinta seus impulsos ou pulsões sexuais (HEILBORN; BRANDÃO, 1999, p. 10).

Sob o olhar tolerante dos pais e da comunidade, os jovens luteranos aprendiam a vivenciar a cultura erótica das sociabilidades, por meio de posturas, gestos, olhares, flertes, namoricos e, por que não, roçar de mãos, de corpos e beijos roubados. Geralmente, o compromisso para o casamento surgia dessa experiência - casamentos endogâmicos, eu reforço. Todavia, a juventude luterana não estava isolada da sociedade curitibana, principalmente se for verdade que era em nível individual que se faziam os contatos permeando as fronteiras étnicas. ${ }^{29}$ No que se refere ao fenômeno urbano, mais acessível aos teuto-brasileiros a partir da segunda geração, enfatizo o papel da cidade na reelaboração dos ambientes “íntimos e familiares”, na expansão das formas de trabalho e na diversificação das áreas públicas e de lazer (TRINDADE, 1996, p. 197). Nessas mudanças estão naturalmente inseridos os luteranos, partícipes das novas preferências sociais dos curitibanos. Assim é que um cronista, passando por cima de certo clima no qual as fronteiras étnicas pareciam ser menos devassáveis, na virada do século XX, escreveu, um tanto ironicamente, que

[...] o perigo alemão manifesta-se ainda na conquista, muito pacífica e elegante, que as senhoritas alemãs estão fazendo dos rapazes brasileiros. Parte notável de nossa mocidade inclina-se fortemente para o lado das graciosas damas loiras e claras, de origem germânica. É verdade que essas damas já são "criolas” cá destes pagos, já têm o donaire das nacionais legítimas. Ainda são, porém, brasileiras, "fritz-mark”, apesar de tudo [...] as nossas patrícias [...] [devem] procurar revanche, conquistando os moços teuto-brasileiros. São uns rapagões desempenados, morigerados, bonitos (alguns), enfim excelentes cortes de maridos. Porque esse povo dá maridos exemplares; dividem com a esposa os trabalhos e as alegrias. É sabido: o alemão casado, quando se diverte, leva consigo o rancho todo e quando acaso vai só não esquece a mulher: traz-lhe do que

\footnotetext{
$\overline{28}$ Ver também Heilborn (1999, p. 41). A ênfase nos contextos deve considerar ainda histórias culturais distintas vividas por descendentes de imigrantes de origem germânica, como é o caso relatado por Willems (1980) a partir de pesquisas realizadas entre 1931 e 1935 em algumas colônias instaladas no Brasil Meridional (os locais não são precisados). Do ponto de vista reprodutivo, o autor enfatiza que a maior fecundidade dos colonos em relação às "populações da antiga estirpe brasileira" dever-se-ia a uma seleção biológica causada pela vida pioneira, aliada à importância de uma prole numerosa e à abundância de terras (WILLEMS, 1980, p. 96-97; 315); nesse sentido, os colonos não conheceriam meios abortivos. Valeria o mesmo com relação a meios anticoncepcionais (WILLEMS, 1980, p. 317). Objetivando a família teuto-brasileira (colonial), o autor analisa as razões da precocidade dos casamentos, a diversidade dos comportamentos sexuais entre os jovens solteiros, com relações pré-nupciais praticamente desconhecidas em algumas colônias, mas frequentes em outras (WILLEMS, 1980, p. 309). Estes costumes seriam herança de antigas instituições (WILLEMS, 1980, p. 304-306), independentemente da moral sexual fundada em sólidos princípios e na importância do casamento (WILLEMS, 1980, p. 317).

${ }^{29}$ Registre-se, ainda, que durante toda a história da comunidade não se contabilizaram mais do que $1 \%$ de nascimentos ilegítimos (com pais desconhecidos ou não nominados nos registros de batismo) (NADALIN, 1988, p. 66). Todas as mães solteiras abrangidas por essas porcentagens eram jovens de sobrenomes germânicos que não consegui identificar entre as famílias da comunidade. Ou seja, estas cifras e constatações devem ser observadas criticamente, pois permitem pensar que mães solteiras poderiam batizar filhos fora da comunidade - inclusive filhos gerados no lado-de-lá das fronteiras étnicas.
} 
comeu ou bebeu, cerveja ou uma rodinha de salsicha. ${ }^{30}$

\section{Considerações finais}

É difícil estabelecer todos os fatores causais relacionados aos comportamentos reprodutivos de grupos etno-culturais resultantes de migrações (FONSECA; LUCAS, 2009, p. 67). 0 que se segue pretende apenas direcionar investigações, considerando as grandes questões discutidas anteriormente, que ajudam a pensar a formatação do grupo social em evidência.

0 primeiro vetor a ser levado em conta tem a ver com o fenômeno dos deslocamentos populacionais, que praticamente dá origem ao grupo. Uma vez que os fluxos migratórios continuam a alimentar a comunidade até praticamente os dias atuais, estou definindo a década de 1930 como limite desses eventos. Assim, a pergunta consequente está pautada na relação entre as migrações e os comportamentos reprodutivos do grupo. Há algum tempo ensaiamos, Alain Bideau e eu, uma metodologia com o objetivo de perscrutar distinções possíveis entre a fecundidade de coortes de casais “mais" e "menos" estáveis na paróquia. Observando os comportamentos respectivos, verificamos que as diferenças, numa primeira apreensão, foram pouco significativas. Entretanto, a idade média das mulheres das coortes "migrantes", ao conceberem o primeiro filho na comunidade, era um pouco mais alta do que a idade daquelas que se casaram na capital paranaense. Isto significa que se perdeu parte da biografia e da história fecunda das migrantes, ao se casarem antes da instalação em Curitiba. As indicações apontam, portanto, para a maior fecundidade dos casais imigrantes, em relação às famílias estáveis (BIDEAU; NADALIN, 2011, p. 91-115).

As migrações de pessoas foram naturalmente acompanhadas de "migrações de ideias". Tanto umas como outras definiam as "correntes sociais" alimentadas pelo imaginário dos migrantes e descendentes, pelas lembranças que permaneceram, modificaram-se e mitificaram-se. Nesse âmbito, a manutenção dessas memórias deve-se às sociações - inter e intrageracionais - desenvolvidas no interior do grupo e aos contatos estabelecidos com indivíduos de fora da comunidade.

Sem dúvida, migração de ideias que têm igualmente como referência o convívio com livros e revistas, publicações - importadas ou não - à disposição dos descendentes de alemães. Nesse sentido, a historiografia destaca o papel das elites urbanas teuto-brasileiras, muitas delas emergentes das regiões coloniais, que tinham gosto pela literatura, pela música, pelas artes (SEYFERTH, 2004) e por novidades de toda ordem, incluindo publicações divulgando o conhecimento científico da época e que poderiam ter como tema, entre outros, a família, o casamento, o papel da mulher, o sexo, etc. (ADLER, [1990]; DEL PRIORE,

\footnotetext{
30 Incluído na tese de Etelvina Trindade (1996, p. 137-138).
} 
2005). ${ }^{31}$ Estas últimas menções conduzem à problemática da sexualidade feminina, cuja história é contada pela historicidade dos gêneros e das próprias mulheres. Livros da lavra geralmente de médicos eugenistas e (ou) higienistas (STEPAN, 2005). ${ }^{32}$ Estes escritos são importantes para entendermos as questões morais e concepções sobre o matrimônio, sobre filhos - enfim, sobre a própria população -, questões que preocupavam a sociedade (DEL PRIORE, 2005, p. 253-255; ENGEL, 1986; SOARES, 1986, p. 143-168).

Naturalmente, muitos destes textos tinham também teor político (MAGALHÃES, 1998). Nesse sentido, poderiam encaminhar para questões relacionadas aos comportamentos reprodutivos, o que me leva a indagar até que ponto os alemães (e muitos dos teuto-brasileiros) estariam impressionados pelos avisos de alguns demógrafos nacionalistas alemães sobre a queda da fecundidade. E, da mesma maneira, pela discussão entre os neomalthusianos e aqueles que refutavam os métodos para controle da população (GAY, 1997, p. 198-200).

Migração de ideias, por fim, que poderia contribuir para o desenvolvimento de preconceitos e manifestações de intolerância do grupo em relação à sociedade curitibana e vice-versa - variáveis próprias da dinâmica do processo da etnicização. Logo, a problematização deve considerar várias questões - que, por enquanto, estão em aberto - e deve ser desenvolvida levando em conta que o grupo nunca constituiu um isolado absoluto, embora eu considere seriamente a hipótese de um enclave inicial sem manifestações étnicas significativas. Assim, é necessário levar em conta o aporte das estruturas culturais anteriores à emigração e a relativa manutenção dessa longa duração como componente da etnicização do grupo a partir de um determinado momento. Em síntese, é preciso ter em mente três questões: a herança cultural e a manutenção da corrente social com as sociedades emissoras; a herança cultural articulada aos novos fluxos migratórios; e as modificações que ocorrem em função do contato com a sociedade anfitriã. Estas questões culminam - em especial, nas "variáveis associadas à multiculturalidade" (FONSECA; LUCAS, 2009, p. 67) - no amadurecimento sexual dos sujeitos e nas mudanças geracionais concernentes à sexualidade.

Tudo isso me leva ao segundo vetor, que considera questões relacionadas aos comportamentos reprodutivos, à cultura da sexualidade das gerações investigadas e ao processo de etnicização das mesmas coortes. Dessa forma, foi enfatizada a necessidade da análise dos contextos específicos dos três períodos recortados, neste caso, ressaltando o conceito de que, se cada indivíduo está inserido numa etno-cultura, que igualmente condiciona o seu comportamento, é evidente que esta influência se estende à sensualidade (FONSECA;

\footnotetext{
${ }^{31}$ Provavelmente devem ter passado pelas mãos de membros da comunidade livros, traduzidos ou não, de Paul Garnier, Marie Carmichael Stopes, Georges Surbled, Paolo Mantegazza, Gustav Adolf Müller e outros, publicados no final do século XIX e início do XX.

32 Gerson Pietta, doutorando no PPGHIS/UFPR e a quem agradeço a colaboração, escreveu-me explicando que, apesar das diferenças na origem dos termos (higiene advém da medicina urbana francesa do século XVIII, da higiene pública e da salubridade, da higiene privada; e eugenia deriva dos estudos ingleses sobre hereditariedade), no Brasil os conceitos quase se confundem, tendo em vista a influência intelectual da Faculdade de Medicina do Rio de Janeiro.
} 
LUCAS, 2009, p. 67). Vale dizer, por conseguinte, que, para compreender essa complexidade, é inevitável a avaliação das prováveis diferenças entre os diversos grupos em contato.

Distintas práticas culturais permitem considerar diferentes atitudes em relação ao corpo, à menstruação, à masturbação, às frequências das atividades sexuais, à sexualidade pré-matrimonial, à utilização de contraceptivos, etc. (FONSECA; LUCAS, 2009, p. 68-69). Em consequência, é natural que aflore uma questão: até que ponto o contato dos imigrantes e teuto-brasileiros com os curitibanos, nos diversos contextos, levaria à construção de uma etno-cultura luterana da sexualidade e dos comportamentos reprodutivos?

A esse problema sobrepõe-se outro: por que ter filhos, por que não tê-los? Todas as indagações propostas consideram, em primeiro lugar, as motivações profundas, inconscientes ou mesmo instintivas referentes à perpetuação da espécie. ${ }^{33}$ Motivações profundas que podem levar em conta a fé luterana, porquanto não ter filhos poderia ser um atentado contra a natureza ou (e) a vontade de Deus. Assim, persiste a dúvida relacionada à teologia característica e pilar de uma Igreja que participou da construção das sociedades ditas "ocidentais". Eu diria que as vertentes sociais que conduziam à aprovação e ao estímulo da fecundidade entre os comungantes, ou, ao contrário, ao ambiente comunitário de um laisser faire que deixava a questão ao arbítrio dos casais, dependeriam bastante do olhar mais ou menos vigilante do pastor sobre o comportamento de suas ovelhas. Voltando ao início da Reforma, é preciso se perguntar até quando teriam persistido os ensinamentos luteranos de que as crianças vêm de Deus, que se encarregaria de alimentá-las. ${ }^{34}$

Lutero insurgia-se contra o culto à castidade e à virgindade característico da Igreja Católica, que tendia a ver na sexualidade uma expressão do pecado original. Para ele, enquanto fenômeno biológico, a atração sexual seria fruto da "boa criação de Deus", e o celibato, uma aberração. Todavia, o "crescei e multiplicai-vos" deveria ser observado no âmbito do casamento, pois, se não fosse assim, a natureza tomaria seu curso por meio da fornicação, do adultério e da masturbação. Ficando com São Paulo na carta aos Coríntios, Martinho pregava que "é melhor casar do que viver abrasado"35 (LUTERO, 2011, p. 160-183).

Em resumo, sexo é bom, mas dentro do casamento. Pela mente do reformador não passaria a possibilidade de comportamentos malthusianos, como ocorreu com parte dos casais da segunda e terceira coortes. De outra parte, é fácil entender como ocorreram concepções antes do casamento entre alguns jovens: ${ }^{36}$ certos prazeres característicos das sociabilidades, sociações lúdicas, poderiam explicar as estatísticas das concepções pré-nupciais. Problema mais complexo é a possibilidade de maior ou menor liberdade no que dizia respeito às relações entre moças e rapazes na fase perigosa do despertar

\footnotetext{
$\overline{33}$ Interessante estudo a respeito foi desenvolvido por MacFarlane (1990) em capítulo intitulado "Custos e benefícios dos filhos".

34 "Gott macht Kinder, der wird sie auch ernähren" (HARDIN, 1967, p. 21). Ampliando esse conceito no que diz respeito ao casamento, ao sexo e aos filhos, ver Lutero (2011, p. 149-296).

${ }^{35}$ Ver também a Confissão de Augsburgo (http://www.mluther.org.br/Luteranismo/Confissao\%20de\%20Augsburgo.htm).

${ }^{36}$ Os números relativos parecem-me importantes, tendo em vista o que informa a historiografia. Ver, por exemplo, Shorter (1973).
} 
da libido. Minha tentação é explicar tudo em função de heranças culturais tradicionais (NADALIN, 2019), mas o contexto dos casamentos ocorridos após 1895 é outro. Assim, é preciso aventar a possibilidade de que os jovens ultrapassavam (certos) limites impostos pelos pais, pelo pastor e pela comunidade, muito em função das fronteiras étnicas que, em alguns níveis, poderiam ser muito tênues.

Deixando de lado o aprofundamento das questões biológicas concernentes, no meu horizonte sempre se delineava a primordialidade em investigar explicações relacionadas aos comportamentos dos luteranos mais jovens, ao vivenciarem os prazeres das sociabilidades. Essas sociações lúdicas traduziam-se variavelmente nas relações de gênero, no namoro e casamento, confinando o erotismo - e, por tabela, outros prazeres -, destacando-se as possíveis heranças de costumes tradicionais mais claramente vigentes na primeira coorte de casais (NADALIN, 2019).

Em parte, estes prazeres foram proporcionados pela utilização de métodos adequados nas relações sexuais e, o que é inerente, pelo planejamento da prole pelos casais, o que Ihes teria sido permitido por uma Weltanschauung adequada. Repetindo o que escrevi alhures (NADALIN, 2004, p. 81), a visão que cada indivíduo tem do mundo depende não só do lugar social que ele ocupa ou da forma como se insere na sociedade organizada, mas também do referencial que tem do passado e de seu amadurecimento psicobiológico e educacional - isto é, da idade. No caso específico, essa inserção dá-se via contatos culturais e por meio da etnicidade. Faço esta consideração pleiteando que a sexualidade manifestada no âmbito de um grupo poderia se originar de culturas em contato, cada uma compondo "entidades sexuadas e socializadas, por intermédio de redes de significados que abarcam categorizações de gênero, de orientação sexual, de escolha de parceiros" (HEILBORN, 1999, p. 40).

Sobre esses comportamentos, do mesmo modo, é preciso aventar as influências de olhares de estranhamento e mesmo preconceituosos de indivíduos compondo grupos sociais do lado-de-lá das fronteiras étnicas. Por outro lado, se as relações entre os rapazes e moças da paróquia luterana caracterizavam-se pela endogamia, tal fato não significa necessariamente que estes jovens estivessem isolados da sociedade curitibana, principalmente se for correta a mencionada hipótese de que era em nível dos indivíduos que se faziam os contatos permeando as fronteiras étnicas.

\section{Referências}

ADLER, L. Segredos de alcova: história do casal de 1830 a 1930. Lisboa: Terramar, 1990.

ANDREAZZA, M. L. Paraíso das delícias: estudo de um grupo imigrante ucraniano. 1895-1995. Tese (Doutorado) - Universidade Federal do Paraná, Curitiba, 1996.

ANDREAZZA, M. L.; NADALIN, S. O. O cenário da colonização no Brasil Meridional e a família imigrante. Revista Brasileira de Estudos de População, v. 11, n. 1, p. 61-87, jan./jun. 1994.

ARIÈS, P. A contracepção no passado. Amor e sexualidade no Ocidente. Edição especial da 
Revista L'Histoire/Seuil. Porto Alegre: L\&PM, 1992. p. 97-111.

BARTH, F. Grupos étnicos e suas fronteiras. In: POUTIGNAT, P.; STREIFF-FENART, J. Teorias da etnicidade. São Paulo: Unesp, 1998. p. 187-227.

BIDEAU, A.; NADALIN, S. O. Étude de la fécondité d'une communauté évangélique luthérienne à Curitiba (Brésil) de 1866 à 1939. Population, v. 43, n. 6, p. 1035-1064, Nov./Dec. 1988.

BIDEAU, A.; NADALIN, S. Une communauté allemande au Brésil. De l'immigration aux contacts culturels, XIXe-XXe siècle. Paris: Ined, 2011.

BÖBEL, M. T.; THIAGO, R. S. Joinville, os pioneiros: documentos e história - 1851 a 1866. Joinville: Ed. Univille, 2001.

BRAUDEL, F. Histoire et sciences sociales; la longue durée. In: BRAUDEL, F. Écrits sur l'Histoire. Paris: Flammarion, 1969. p. 41-83.

BUENO, A. M. Representações discursivas do imigrante a partir de 1945. Tese (Doutorado) Universidade de São Paulo (USP), São Paulo, 2011.

BURGUIĖRE, A. Les rapports entre générations: un problème pour l'historien. Communications, n. 59, p. 15-27, 1994.

CAMARGO, C. P. F. de. A dinâmica populacional como processo histórico-social. In: SANTOS, J.; LEVY, M. S. F.; SMERECZÁNYI, T. (org.). Dinâmica da população: teoria, métodos e técnicas de análise. São Paulo: T.A. Queiros, 1980. p. 12-18.

COLOGNESE, S. A. Gerações, fronteiras e italianidade no Sul do Brasil. Tempo da Ciência, v. 18, n. 36, p. 137-152, 20 - semestre 2011. Disponivel em: http://e-revista.unioeste.br/index.php/ tempodaciencia/article/view/9049. Acesso em: 5 ago. 2019.

COONTZ, S. Historia del matrimonio: como el amor conquisto el matrimonio. Barcelona: Gedisa, 2006.

CORBIN, A. A pequena Bíblia dos jovens nubentes. Amor e sexualidade no Ocidente. Edição especial da Revista L'Histoire/Seuil. Porto Alegre: L\&PM, 1992. p. 201-211.

CUCHE, D. A noção de cultura nas ciências sociais. 2. ed. Bauru: Edusc, 2002.

DEL PRIORE, M. História do amor no Brasil. São Paulo: Contexto, 2005.

DICIONÁRIO Demográfico multilingue. [Rio de Janeiro]: Fundação IBGE, 1969. Disponível em: https://biblioteca.ibge.gov.br/visualizacao/livros/liv14136.pdf. Acesso em: 18 jul. 2019.

ENGEL, M. O médico, a prostituta e os significados do corpo. In: VAINFAS, R. (org.). História e sexualidade no Brasil. Rio de Janeiro: Graal, 1986. p. 169-190.

FABRIS, P. “Nós, os selvagens, não reverenciamos os symbolos kayserianos": conflitos em torno de uma identidade germânica em Curitiba (1890-2014). Dissertação (Mestrado) - Universidade Federal do Paraná (UFPR), Curitiba, 2014.

FLANDRIN, J.-L. Um temps pour embrasser: aux origines de la morale sexuelle occidentale (Vle. XIe siécle). Paris: Seuil, 1983.

FONSECA, F.; LUCAS, M. C. Sexualidade, saúde e contextos: influência da cultura e etnia no comportamento sexual. Revista Portuguesa de Medicina Geral e Familiar, v. 25, n. 1, p. 65-72, 2009. Disponivel em: http://www.rpmgf.pt/ojs/index.php/rpmgf/article/view/10592. Acesso em: 18 abr. 2019.

FOUCAULT, M. História da sexualidade: I. A vontade de saber. 2. ed. Rio de Janeiro: Graal, 1977. 
GARNIER, P. O matrimônio: considerado nos seus deveres, relações e effeitos conjugaes do ponto de vista legal, hygienico, phisiologico e moral. Rio de Janeiro/Paris: Garnier, s/d.

GARNIER, P. A geração universal: leis, segredos e mysterios no homem e na mulher. Rio de Janeiro/Paris: Garnier, s/d.

GAY, P. A experiência burguesa da Rainha Vitória a Freud: a educação dos sentidos. São Paulo: Cia. das Letras, 1988.

GREEN, N. Tempo e estudo da assimilação. Antropolítica, n. 25, p. 23-47, 2ํ sem. 2008.

HALBWACHS, M. Morphologie sociale. 1938. Disponivel em: http://classiques.uqac.ca/ classiques/Halbwachs_maurice/morphologie/morphologie.html. Acesso em: 04 jun. 2018.

HANSEN, M. L. The problem of the third generation immigrant. Rock Island: Augustana Historical Society Publications, 1938. Disponível em: https://babel.hathitrust.org/cgi/ pt?id=inu.30000118510415;view=1up;seq=5. Acesso em: 05 ago. 2019.

HARDIN, G. (org.). População, evolução e contrôle da natalidade. São Paulo: Editora Nacional, 1967.

HEILBORN, M. L. Construção de si, gênero e sexualidade. In: HEILBORN, M. L. (org.). Sexualidade: o olhar das ciências sociais. Rio de Janeiro: Jorge Zahar, 1999.

HEILBORN, M. L.; BRANDÃO, E. R. Ciências sociais e sexualidade. In: HEILBORN, M. L. (org.). Sexualidade: o olhar das ciências sociais. Rio de Janeiro: Jorge Zahar, 1999.

HENRY, L. Manuel de démographie historique. Genève-Paris: Droz, 1970.

HOBSBAWM, E. J. A era dos impérios: 1875-1914. 9. ed. Rio de Janeiro: Paz e Terra, 2005.

HUBER, V. A literatura da imigração alemã e a imagem do Brasil. Disponível em: http://www. letras.ufrj.br/liedh/media/docs/art_valb2.pdf. Acesso em: 12 jul. 2019.

KREAGER, P. Demographic regimes as cultural systems. In: COLEMAN, D.; SCHOFIELD, R. The state of population theory. Londres: Oxford Basil Blackwell Ltda., 1986.

LAPIERRE, J.-W. Prefácio. In: POUTIGNAT, P.; STREIFF-FENART, J. Teorias da etnicidade. São Paulo: Unesp, 1998.

LAQUEUR, T. Inventando o sexo: corpo e gênero dos gregos a Freud. Rio de Janeiro: Relume Dumará, 2001.

LOYOLA, M. A. A sexualidade como objeto de estudo das ciências humanas. In: HEILBORN, M. L. (org.). Sexualidade: o olhar das ciências sociais. Rio de Janeiro: Jorge Zahar, 1999. p. 31-39.

LUTERO, M. Obras selecionadas. Ética: fundamentos - oração - sexualidade - educação economia, v. 5. São Leopoldo: Sinodal; Porto Alegre: Concórdia, 2011.

MACFARLANE, A. História do casamento e do amor: Inglaterra, 1300-1840. São Paulo: Companhia das Letras, 1990.

MACHADO, C. da S.; NADALIN, S. O. Memória individual e discurso social; Curitiba na passagem do século XIX para o século XX (posfácio). In: STROBEL, G. H. Memórias de Gustav Hermann Strobel: relatos de um pioneiro da imigração alemã no Brasil. 3. ed. Curitiba: Instituto Memória, 2018. p. 193-219.

MAGALHÃES, M. D. B. de. Pangermanismo e nazismo: a trajetória alemã rumo ao Brasil. Campinas: Edit. Unicamp/Fapesp, 1998.

MAGALHÃES, M. D. B. de; NADALIN, S. O. Imigração germânica, etnicidade e identidade ocupacional/profissional. Colonização em Joinville (Dona Francisca), Província de Santa Catarina. História, v. 38, e2019014, 2019. 
MANNHEIM, K. O problema sociológico das gerações. In: FORACCHI, M. M. (org.). Mannheim. São Paulo: Ática, 1982.

MANTEGAZZA, P. 0 amor dos homens: ensaio de uma ethnologia do amor. Lisboa: Tavares Cardoso \& Irmão, 1904.

MCLAREN, A. História da contracepção da antiguidade à actualidade. Lisboa: Terramar, 1997.

MOTTA, A. B. da. Gêneros, idades e gerações; introdução. Cadernos CRH, Salvador, v. 17, n. 42, p. 349-355, set./dez. 2004.

MÜLLER, G. A. Liebe-Ehe-Schlafgemach: sexual-ästhetische Gedanken und Raschläge. Berlin: Dr. Basch \& Co. G.m.b.H., s/d.

MURSTEIN, B. Amor, sexo e casamento através dos tempos. v. 3. Rio de Janeiro: Artenova, 1978.

NADALIN, S. O. Clube Concórdia. Curitiba: Clube Concórdia, 1972.

NADALIN, S. O. Une paroisse d'origine germanique au Brésil: la Communauté Évangelique Luthérienne a Curitiba entre 1866 et 1969. Doctorat 3e Cycle, Ecole des Hautes Études en Sciences Sociales, 1978.

NADALIN, S. O. Imigrantes alemães e descendentes em Curitiba; caracterização de um grupo social. História: Questões \& Debates, v. 2, n. 2, p. 23-35, jun. 1981.

NADALIN, S. O. Sexualidade, casamento e reprodução. Revista Brasileira de Estudos de População, v. 5, n. 2, p. 63-91, jul./dez. 1988.

NADALIN, S. O. História e demografia: elementos para um diálogo. Campinas: Abep, 2004.

NADALIN, S. O. Imigração e família, segunda metade do século XIX. Revista Latinoamericana de Población, v. 8, n. 14, p. 31-55, enero-junio 2014.

NADALIN, S. O. A respeito de uma demografia histórica de contatos culturais. Cadernos de História, v. 9, n. 11, p. 11-31, 1ํsem. 2007. Disponível em: http://periodicos.pucminas.br/index. php/cadernoshistoria/article/view/2880. Acesso em: 05 ago. 2019.

NADALIN, S. O. Sociabilidades e sexualidade; o enclave imigrante germânico em Curitiba: 1866-1894. In: DORÉ, A.; RIBEIRO, L. C. (org.). O que é sociabilidade. São Paulo: Intermeios, 2019. p. 163-182.

NADALIN, S. O.; FABRIS, P. A comunidade alemã em Curitiba e a conjuntura da Primeira Grande Guerra. Revista de História Regional, v. 18, n. 1, p. 7-30, 2013. Disponível em: http://www. revistas2.uepg.br/index.php/rhr/article/viewFile/5130/3511.

OLIVEIRA, J. et al. Padrão hormonal feminino: menopausa e terapia de reposição. Revista Brasileira de Análises Clínicas, v. 48, n. 3, p. 198-210, 2016. Disponível em: http://www.rbac.org. br/wp-content/uploads/2016/11/ARTIGO-3_RBAC-48-3-2016-ref.-20.pdf. Acesso em: 17 abr. 2019.

POUTIGNAT, P.; STREIFF-FENART, J. Teorias da etnicidade. São Paulo: Unesp, 1998.

PRIEN, H.-J. Formação da Igreja Evangélica no Brasil: das comunidades teuto-evangélicas de imigrantes até a Igreja Evangélica de Confissão Luterana no Brasil. São Leopoldo: Sinodal; Petrópolis: Vozes, 2001.

RESSEL, L. B.; GUALDA, D. M. R. A sexualidade como uma construção cultural: reflexões sobre preconceitos e mitos inerentes a um grupo de mulheres rurais. Revista da Escola de Enfermagem da USP, v. 37, n. 3, p. 82-87, 2003. Disponível em: http://www.scielo.br/pdf/reeusp/v37n3/10. pdf. Acesso em: 22 abr. 2019.

RIBEIRO, B. Protestantismo no Brasil Monárquico, 1822-1888: aspectos culturais de aceitação do protestantismo no Brasil. São Paulo: Pioneira, 1973. 
ROHDEN, F. A arte de enganar a natureza: contracepção, aborto e infanticídio no início do século XX. Rio de Janeiro: Fiocruz, 2003.

SAHLINS, M. Ilhas de história. Rio de Janeiro: Jorge Zahar, 2003.

SCHWARCZ, L. M. O espetáculo das raças: cientistas, instituições e questão racial no Brasil, 1870-1930. São Paulo: Cia das Letras, 1993.

SCHWARCZ, L. M. Marshall Sahlins ou por uma antropologia estrutural e histórica. Cadernos de Campo, v. 9, n. 9, p. 125-133, 2000.

SEGALEN, M. Sociologie de la famille. Paris: A. Colin, 1993.

SEYFERTH, G. Nacionalismo e identidade étnica: a ideologia germanista e o grupo étnico teuto-brasileiro numa comunidade do Vale do Itajaí. Florianópolis: Fundação Catarinense de Cultura, 1981.

SEYFERTH, G. A identidade teuto-brasileira numa perspectiva histórica. In: MAUCH, C.; VASCONCELLOS, N. (org.). Os alemães no Sul do Brasil. Canoas: Editora Ulbra, 1994. p. 11-27.

SEYFERTH, G. A conflituosa história da formação da etnicidade teuto-brasileira. In: FIORI, N. A. (org.). Etnia e educação: a escola "alemã” do Brasil e estudos congêneres. Florianópolis: Ed. da UFSC; Tubarão: Editora Unisul, 2003.

SEYFERTH, G. A idéia de cultura teuto-brasileira: literatura, identidade e os significados da etnicidade. Horizontes Antropológicos, Porto Alegre, v. 10, n. 22, p. 149-147, jul./dez. 2004.

SHORTER, E. Female emancipation, birth control, and fertility in European history. The American Historical Review, v. 78, n. 3, p. 607-640, June 1973.

SHORTER, E. A formação da família moderna. Lisboa: Terramar, 1995.

SILVEIRA, E. A cura da raça: eugenia e higienismo no discurso médico sul-rio-grandense nas primeiras décadas do século XX. Passo Fundo: Ed. Universidade de Passo Fundo, 2005.

SIMMEL, G. Questões fundamentais da Sociologia: indivíduo e sociedade. Rio de Janeiro: Jorge Zahar, 2006.

SOARES, L. C. Da necessidade do bordel higienizado; tentativas de controle da prostituição carioca no século XIX. In: VAINFAS, R. (org.). História e sexualidade no Brasil. Rio de Janeiro: Graal, 1986. p. 143-168.

STEARNS, P. N. História da sexualidade. São Paulo: Contexto, 2010.

STEPAN, N. L. "A hora da eugenia": raça, gênero e nação na América Latina. Rio de Janeiro: Fiocruz, 2005.

STOPES, M. C. Amor e casamento: nova contribuição para a solução do problema sexual. São Paulo: Cia. Editora Nacional, 1929.

STOPES, M. C. Procreação racional. Complemento pratico da obra "Amor e Casamento". São Paulo: Cia. Editora Nacional, 1929.

STROBEL, G. H. Memórias de Gustav Hermann Strobel: relatos de um pioneiro da imigração alemã no Brasil. Curitiba: Instituto Memória, 2018.

SURBLED, G. A moral nas suas relações com a medicina e a higiene. 4 v. Porto: Editora Educação Nacional, 1939/1940.

TANNAHILL, R. Le sexe dans l’Histoire. Paris: Robert Laffont, 1982. 
TRINDADE, E. M. de C. Clotildes ou Marias: mulheres de Curitiba na Primeira República. Curitiba: Fundação Cultural, 1996.

WACHTEL, N. L'aculturation. In: LE GOFF, J.; NORA, P. Faire l'histoire, t. 1: Nouveaux problèmes. Paris: Gallimard, 1974.

WILLEMS, E. A aculturação dos alemães no Brasil. Estudo antropológico dos imigrantes alemães e seus descendentes no Brasil. 2. ed. São Paulo: Editora Nacional, 1980.

\section{Sobre 0 autor}

Sergio Odilon Nadalin é professor aposentado, colaborador do Programa de Pós-Graduação em História da Universidade Federal do Paraná (UFPR), bolsista sênior do CNPq.

\section{Endereço para correspondência}

Rua Bororós, 555

80320-260 - Curitiba-PR, Brasil

\section{Abstract \\ Immigration, ethnic borders and sociabilities: theoretical issues}

The reference for this text are the subjects grouped socially and culturally from a process of emigration/immigration, whose structures refer back to the migrant societies. Following the settlement in Curitiba, the group gradually transforms itself when in contact with Brazilian society and with other groups of immigrant origin, erecting ethnic boundaries. One of the directions of the research involved conducting an analysis of reproductive behaviors of immigrants and descendants. The goal, at this stage, is to overcome the why to try to solve the problem of how, despite the absence of "qualitative" documentation that would allow us to discern the intimacy of the sampled couples. The purpose of the text is to pose some theoretical and methodological questions considering the role of individuals within the concept of sociability. That is, in the sphere of individual-society relations, the idea is to consider the theoretical variables that could help understand what the numbers seem to expose. For this, interpersonal relationships are taken into consideration - including intra and intergenerational living - within the boundaries of the aforementioned borders. To this end, the analysis favors contexts that allow for the synthesizing of ethnicity dynamics. The text also seeks a theoretical-methodological balance focusing on my research, oriented, in a broader epistemological sense, by "demographic" studies; baseline data were sampled from the methodology of family reconstitution.

Keywords: Immigration. Ethnicity. Sociability. Generation. Sexuality. Reproductive behaviors. 


\section{Resumen}

Inmigración, fronteras étnicas y sociabilidades: cuestiones teóricas

El texto tiene como referencia sujetos agrupados social y culturalmente a partir de un proceso de emigración/inmigración, cuyas estructuras remontan a las sociedades emisoras. Transcendiendo el establecimiento en Curitiba, el grupo, en contacto con la sociedad brasileña y con otros agrupamientos de origen inmigrante, se transforma gradualmente y erige fronteras étnicas. Uno de los direccionamientos de la investigación fue conducido por el análisis de los comportamientos reproductivos de los inmigrantes y sus descendientes. El objetivo, en esta etapa, es adelantar el porqué para intentar resolver el problema del cómo, a pesar de la ausencia de documentación cualitativa que permitiría discernir la intimidad de las parejas muestrados. De ese modo, se presentan algunas cuestiones teórico-metodológicas al considera el papel de los individuos, en el ámbito del concepto de las sociabilidades. O sea, en la esfera de las relaciones individuo-sociedad, se investiga cuáles serían las variables teóricas que podrían ayudar a entender lo que los números parecen denunciar. Para eso, se consideran las relaciones interpersonales -incluyendo la convivencia intra e intergeneracional- en los límites de las mencionadas fronteras. Con esa finalidad, el análisis privilegia contextos que permiten sintetizar la dinámica de la etnicidad. Igualmente, se propone un balance teórico-metodológico teniendo como foco mis investigaciones, orientadas, en un sentido epistemológico más laxo, por estudios demográficos. Los datos de base fueron recogidos a partir de la metodología de la reconstitución de familias.

Palabras clave: Inmigración. Etnicidad. Sociabilidad. Generación. Sexualidad. Comportamientos reproductivos. 